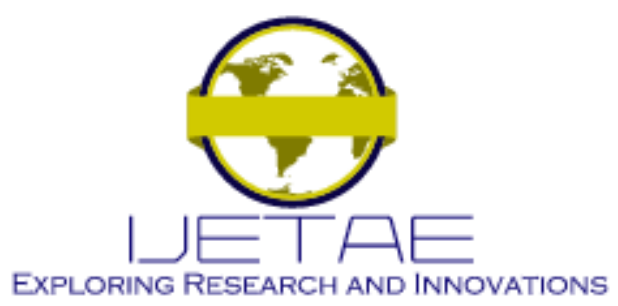

International Journal of Emerging Technology and Advanced Engineering

Website: www.ijetae.com (E-ISSN 2250-2459, Scopus Indexed, ISO 9001:2008 Certified Journal, Volume 11, Issue 11, November 2021)

Manuscript Received: 03 October 2021, Received in Revised form: 01 November 2021, Accepted: 12 November 2021

DOI: $10.46338 /$ ijetae1121_26

\title{
Designing Knowledge Management System with Big Data for Data and Information Center Ministry of Health Indonesia
}

\author{
Adrian Suherman ${ }^{1}$, Gunawan Wang ${ }^{2}$ \\ Information Systems Management Department, BINUS Graduate Program-Master of Information Systems Management, Bina \\ Nusantara University, Jakarta, Indonesia 11480
}

\begin{abstract}
Sharing and capture knowledge is one of the important indicators in the ministry of health. The role of staff's knowledge is a benchmark in determining service performance and quality, in this case the Knowledge Management System (KMS) is a solution in supporting the process of knowledge capture and knowledge sharing. However, the growth of innovation in knowledge management is also required in practice. The implementation of big data into the Knowledge Management System plays a role in extracting, transforming, loading, which can help the information system development division and this information technology and infrastructure management subdivision to collect, filter and combine data from various sources. The results of the KMS design are in the form of a site-based application that has a wiki module, discussion forums and document management to share medical experiences and there are search features needed by staff.
\end{abstract}

Keywords-Knowledge, Knowledge Management, KMS, Big Data

\section{INTRODUCTION}

The era of information technology is very fast, making competition in the business world to be tighter. Companies or organizations are competing to create a service that can sustain their business, especially in this dynamic business competition era. Therefore, both companies and organizations must have a good and sustainable strategy to be able to adapt to the changes that will occur. One of the strategies and special concerns of a company or organization in this dynamic business competition is to fully pay attention to the human resources that exist within the organization or company.

The rapid growth of data and technology at this time has led to the transformation of data into information and then this valuable information into knowledge [1]. The growth of data and technology is also matched by the increasing number of people who realize the value or value of knowledge and the ways to obtain, recognize, capture, store, and use it so that knowledge can be shared among individuals.
The amount of knowledge that is abundant in an organization or company makes the organization grow and develop from various business sectors.

The existence of information technology assistance in terms of sharing knowledge within organizations and companies is an easy thing to do. One of the technologies that organizations and companies often use in sharing knowledge is knowledge management (KM), where knowledge management can help disseminate knowledge more quickly and easily. The definition of knowledge management is a series of activities or processes that can help companies or organizations identify, organize, disseminate and transfer existing knowledge within the organization or company [2]. In existing companies and organizations, the knowledge management that is owned can only be accessed internally in the company itself so that the knowledge held is not leaked to parties outside the organization or company. Merali said that intranet and internet technology can help organizations to support knowledge management within the company [3].

The development of the times also makes the demand for public services higher, where this government institution must be able to adapt and overcome this dynamic environment so that this public service can finally meet its target, namely serving the community. The many and varied demands remind that the importance of information and knowledge in a government institution. In this study, the object to be studied is the Data and Information Center Ministry of Health. The Data and Information Center of the Ministry of Health has a helpdesk section where the helpdesk is part of the subdivision of infrastructure and information technology management and within the Data and Information Center itself there is an information system development division. The helpdesk here is tasked with solving a problem in services related to networks, video conferencing and data centers at the ministry of health. The staff at the helpdesk are also few but do so many services. 


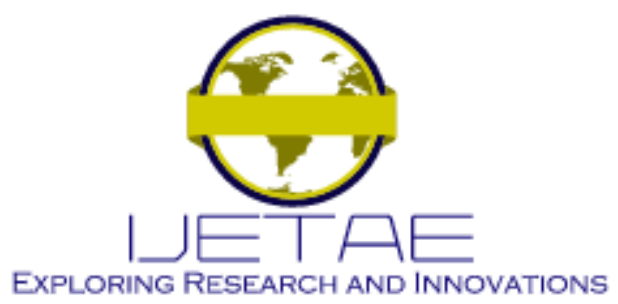

International Journal of Emerging Technology and Advanced Engineering

Website: www.ijetae.com (E-ISSN 2250-2459, Scopus Indexed, ISO 9001:2008 Certified Journal, Volume 11, Issue 11, November 2021)

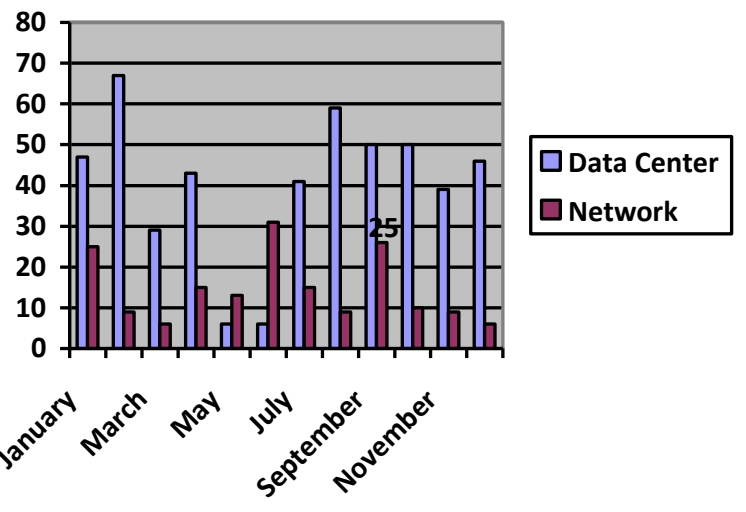

Figure 1: Incident Graph 2020

Table 1

Incident Table 2020

\begin{tabular}{|c|c|c|}
\hline & Data Center & Network \\
\hline January & 47 & 25 \\
\hline February & 67 & 9 \\
\hline March & 29 & 6 \\
\hline April & 43 & 15 \\
\hline May & 6 & 13 \\
\hline June & 6 & 31 \\
\hline July & 41 & 15 \\
\hline August & 59 & 9 \\
\hline September & 50 & 26 \\
\hline October & 50 & 10 \\
\hline November & 39 & 9 \\
\hline December & 46 & 6 \\
\hline Total & 483 & 174 \\
\hline
\end{tabular}

From incident graph 2020, helpdesk resolved 483 problems about data center and 174 problems about network so the total problems which handled by helpdesk is 657 problems.
From here the helpdesk staff must be able to quickly solve IT problems that occur in the ministry of health with limited staff. The staff in the subdivision of infrastructure and information technology management as well as staff in the information system development division already have knowledge of both tacit knowledge and explicit knowledge, but do not yet have a place or place to store knowledge about the helpdesk. In the information system development division, only a few employees are experts in the IT field and employees in the information system development division rarely document every stage in developing an information system, be it the requirements, design, coding and validation stages to users. These two divisions want a more structured knowledge storage container and the knowledge contained in these two divisions is also in various forms, be it PDF, Word, Excel, PPT, photos, Youtube, Social Media. Problems like this can be overcome by implementing a knowledge management system. With the availability of a container that stores various kinds of information and knowledge which will later be used by the subdivision of infrastructure management and information technology as well as the information system development division, it is hoped that the distribution of information to employees in these divisions and subdivisions will be able to overcome problems and facilitate the work of employees in solving problems. a problem. In this study, the framework used is a combination of the Tiwana framework and the KMSAIM framework along with the knowledge grouping based on Debowski. The use of big data, especially in the use of extract, transform, load can help these two divisions to collect, filter and combine data from various sources to be stored in the data warehouse. Then data warehouse can give recommendations.

\section{LITERATURE REVIEW}

\section{A. Knowledge}

Knowledge is something that is obtained through understanding, facts or from a thought [4]. Knowledge can also mean a collection of facts, opinions, perceptions and ideas as well as choices and beliefs and experiences [5]. According to Nonaka and Takeuchi, knowledge can be divided into 2, namely Tacit Knowledge and Explicit Knowledge [6]. Tacit knowledge is knowledge contained in the person's own mind is in accordance with the understanding and experience felt by the person. 


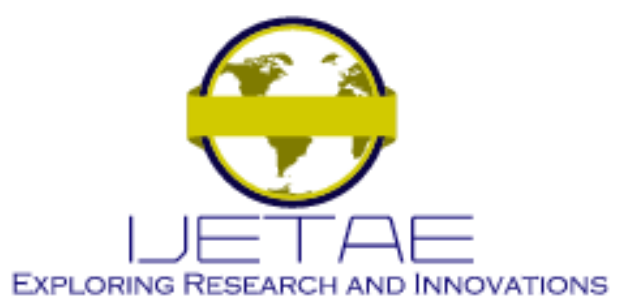

International Journal of Emerging Technology and Advanced Engineering

Website: www.ijetae.com (E-ISSN 2250-2459, Scopus Indexed, ISO 9001:2008 Certified Journal, Volume 11, Issue 11, November 2021)

Tacit knowledge is basically more personal in nature and developed with difficult experiences so that it is difficult to formulate and communicate. Explicit knowledge is knowledge that has been translated into the form of documentation or summaries so that it can be shared and easily understood by others. Explicit knowledge is knowledge that is formal and systematic to be shared and communicated to many people [7].

\section{B. SECI Model}

Nonaka and Takeuchi with tacit knowledge have provided an overview of how knowledge is viewed by people. Initially, tacit knowledge only became knowledge that was realized by individuals and could not be expressed, then Nonaka and Takeuchi's theory has opened the way to view tacit knowledge as a type of knowledge that has enormous potential and value in an organization. According to Nonaka and Takeuchi, knowledge is made explicit. This idea forms the basis of the knowledge conversion theory, namely the SECI model. This SECI model contains knowledge that is socialized (socialization), externalized (externalization), combined (combination) and internalized (internalization) in a continuous spiral process [6].

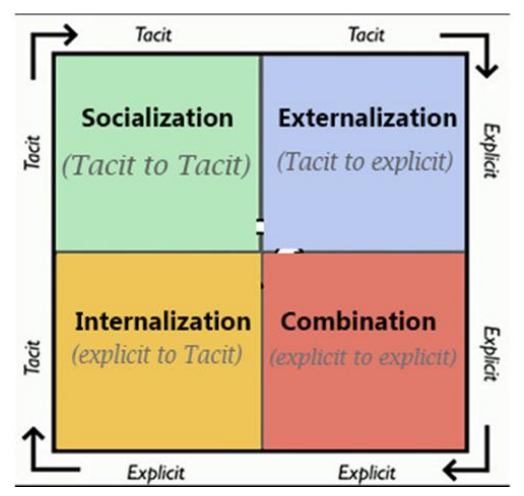

Figure 2: SECI Model

\section{Knowledge Management}

Knowledge management is a collaborative and integrated approach to the creation, retrieval, organization and use of assets within a company. Knowledge management is a set of processes for creating and sharing knowledge throughout the organization to achieve the mission and goals of an organization [8]. Knowledge management is a systematic coordination within an organization that manages human resources, technology, organizational structures and processes to increase value and innovation in an organization [9].

\section{Knowledge Management System}

Knowledge management system is a technology that supports knowledge management in regeneration and sharing knowledge in an organization [10]. Knowledge management system is an information system that helps the process of creating, storing, remembering and applying knowledge in a company/organization [11]. Knowledge management system is designed with the creation, sharing and storage of knowledge. Knowledge management system is an information system in the field of knowledge that supports the creation, management and dissemination of knowledge to people within an organization [12].

\section{E. The 10 Step Knowledge Management Road Map}

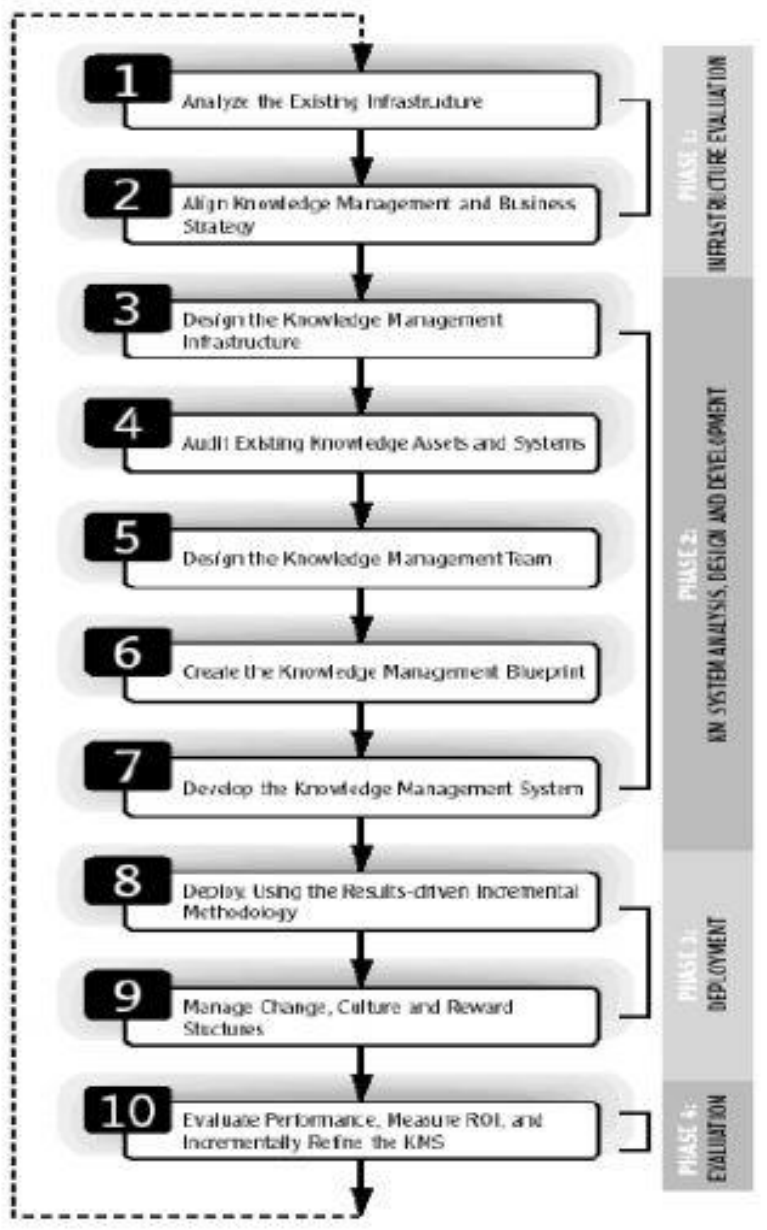

Figure 3: The 10 Step Knowledge Management Road Map 


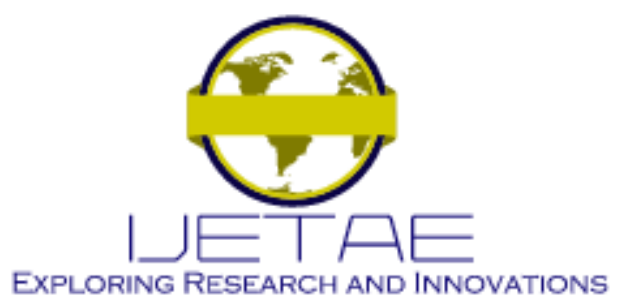

International Journal of Emerging Technology and Advanced Engineering

Website: www.ijetae.com (E-ISSN 2250-2459, Scopus Indexed, ISO 9001:2008 Certified Journal, Volume 11, Issue 11, November 2021)

Tiwana made 10 step guides for creating and evaluating knowledge management which can be used as guidelines for creating a knowledge management system [13]. The 10 steps in creating a knowledge management system are divided into 4 phases, namely:

\section{1) Infrastructure evaluation}

Infrastructure evaluation is concerned with analyzing existing infrastructure and integrating knowledge management with business strategy.

2) Knowledge management system analysis, design, and development

This section deals with the design of knowledge management infrastructure, design of a knowledge management team, auditing and analyzing existing knowledge, making knowledge management blueprints and developing a knowledge management system.

\section{3) System deployment}

System deployment relates to testing a knowledge management system, managing change, culture and reward systems.

\section{4) ROI and performance evaluation}

This phase deals with evaluating the benefits of the knowledge management system and developing a knowledge management system on a regular basis.

Tiwana Framework that used for designing knowledge management system for Data and Information Center Ministry of Health Indonesia are align KM and business strategy, design the knowledge management blueprint and develop KMS. Allign KM and business strategy for knowledge mapping or content management layer. Design the knowledge management blueprint for create KMS architecture. Develop KMS is relate to create user interface.

\section{F. KMSAIM Framework}

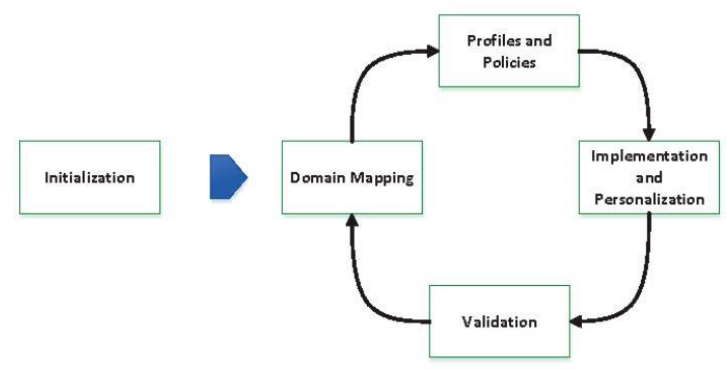

Figure 4: KMSAIM Framework
KMSAIM stands for Knowledge Management System Agile Implementation Methodology. The KMSAIM framework is built on agile methodologies [14]. The KMSAIM framework was proposed because the framework for designing the existing knowledge management system was deemed quite time-consuming, budgetary and resource-consuming so that it could pose a risk of failure to implement the existing knowledge management system and framework, which does not focus on client collaboration. In fact the KMSAIM framework requires very few resources and agile methods are well suited for cloud-based development. The KMSAIM framework places more emphasis on identification or initialization stages in depth in order to get details of business processes. These are the phases in the KMSAIM framework:

\section{1) Initialization}

In the initialization phase, an implementation team is formed and knows the conditions and requirements of the users. The implementation team also knows the business domain. This phase also has a goal, namely to get an overview of the organization, knowledge within the company, the flow of knowledge within the company and business concepts

\section{2) Domain Mapping}

This domain mapping phase handles the development of the concepts to be designed and the relationship between concepts in the business domain that are adapted to business processes and the main components of knowledge management, namely people, process and technology. This phase aims to determine what functions must be carried out based on the initialization phase, namely processes and business domains and what technology will be used.

\section{3) Profiles and Policies}

This phase contains users who can manage the knowledge management system along with access to a user. In this phase, a user must be determined who will manage the knowledge management system and determine access rights and the authority or scope of a user.

\section{4) Implementation and Personalization}

The implementation and personalization phase is related to the design of the knowledge management system that will be made starting from the infrastructure and architecture design and contains the knowledge management system blueprint. 


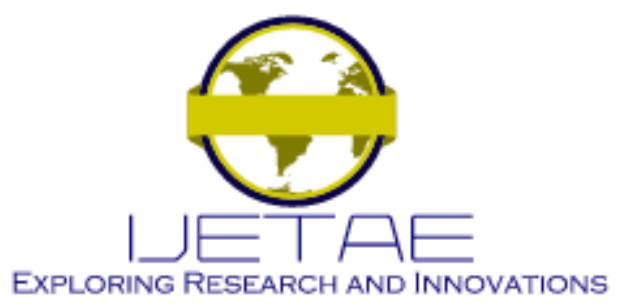

International Journal of Emerging Technology and Advanced Engineering

Website: www.ijetae.com (E-ISSN 2250-2459, Scopus Indexed, ISO 9001:2008 Certified Journal, Volume 11, Issue 11, November 2021)

The implementation and personalization phase is also related to the transformation of requirements into a module that is built using the selected tools.

\section{5) Validation}

This validation phase contains the design of a knowledge management system that has been created and then tested in the form of an application that is in accordance with the knowledge management system blueprint.

KMSAIM Framework for designing knowledge management system for Data and Information Center Ministry of Health Indonesia are domain mapping and profiles and policies. Domain mapping for map the user's requirement. Profile and policies for create the scope for user.

\section{G. Big Data}

Big data contains exponentially increasing complex and unstructured data quickly and data accumulates with remote profiling options. Big data is a structure that analyzes conventional database management using an analysis system. Big data is a large variety of data with unstructured data with conceptual innovations that have been used in various fields [15]. Big data is data that has 4 characteristics, namely volume, veracity, variety and velocity.

\section{H. KMS with Big Data}

One strategy for managing sharing, capture and create new knowledge through KMS is use big data. Big data can extract information from structure data and unstructured data from many sources [16]. It can help staff to create knowledge from many resources to improve service for Ministry of Health Indonesia.

\section{ETL}

Extract, transform and load (ETL) is the core process of data integration and is often associated with data warehouses [16]. ETL functions to integrate data by involving extracting data from outside sources and then converting it according to business needs and finally entering it into the data warehouse. In the extract, transform and load (ETL) process, the role is to extract data, convert data and enter it into the data warehouse. Extraction is the process of retrieving relevant data sources. Transformation is related to the data cleaning process. Loading is the process of transferring data to a data warehouse [17].
An easy way to comply with the conference paper formatting requirements is to use this document as a template and simply type your text into it.

\section{Methodology}

The design model in this study begins by defining the domain mapping. Then, the second step is to define profile and policies. The third step is to create a knowledge management blueprint. The fourth step is to design the integration of big data with the knowledge management system and ends with the Design Knowledge Management System User Interface.

\section{A. Domain Mapping}

The first phase is to do a domain mapping. This phase contains what is needed by the organization based on the knowledge management architecture.

\section{B. Knowledge Mapping}

The second phase is knowledge mapping. Where in this phase, the existing knowledge grouping is carried out in the information system development division and the infrastructure and information technology management subdivision.

\section{Profile and Policies}

This profile and policies stage determines users and what users can do in a knowledge management system and also provides access according to users. Any scope restrictions will also be defined at this stage. In this third stage, a use case will also be made.

\section{Design and Integrating Big Data}

In this phase, we design a big data framework in the form of an architecture and how to map big data with knowledge management.

\section{E. Design Knowledge Management System User Interface}

At the stage of developing a knowledge management system in this research, create a user interface design for a knowledge management system. The prototype design made will be web-based on desktop and mobile.All paragraphs must be indented. All paragraphs must be justified, i.e. both left-justified and right-justified.

\section{RESUlt AND Discussion}

The design model in this study begins by defining the domain mapping 


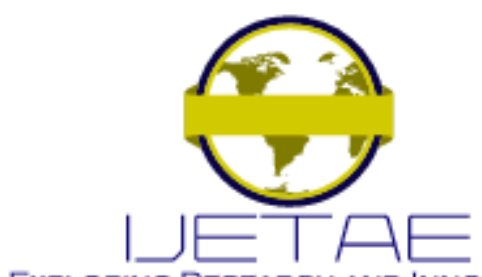

\section{EXPLORING RESEARCH AND INNOVATIONS}

\section{International Journal of Emerging Technology and Advanced Engineering}

Website: www.ijetae.com (E-ISSN 2250-2459, Scopus Indexed, ISO 9001:2008 Certified Journal, Volume 11, Issue 11, November 2021)

\section{A. Domain Mapping}

In Domain Mapping phase, it contains the requirements of Infrastructure and Information Technology Management Subdivision and Information System Development Division.

\section{1) Requirement from Infrastructure and Information Technology Management Subdivision}

Table 2:

Requirement from Infrastructure and Information Technology Management Subdivision

\begin{tabular}{|l|l|}
\hline Requirement & Module \\
\hline $\begin{array}{l}\text { Existence of explicit knowledge documentation to make } \\
\text { it easier to solve a problem case from the admin } \\
\text { helpdesk }\end{array}$ & Wiki \\
\hline Exchange of employee's explicit knowledge & Wiki \\
\hline $\begin{array}{l}\text { Documenting the results of one-way discussions } \\
\text { between the staff of the infrastructure management and } \\
\text { information technology division }\end{array}$ & Forum \\
\hline $\begin{array}{l}\text { There is a module in knowledge management that can } \\
\text { replace Whatsapp as a place for previous discussions }\end{array}$ & Forum \\
\hline
\end{tabular}

2) Requirement from Information System Development Division

Table 3:

Requirement from Information System Development Division

\begin{tabular}{|l|l|}
\hline Requirement & Module \\
\hline $\begin{array}{l}\text { There is documentation of the stages of a project } \\
\text { work }\end{array}$ & Wiki \\
\hline $\begin{array}{l}\text { There is knowledge sharing among employees of the } \\
\text { information system development division }\end{array}$ & Forum \\
\hline $\begin{array}{l}\text { There is document management, where the } \\
\text { documents can also be downloaded (such as letters for } \\
\text { projects) }\end{array}$ & $\begin{array}{l}\text { Document } \\
\text { Management }\end{array}$ \\
\hline
\end{tabular}

\section{B. Knowledge Mapping}

In the knowledge mapping phase, the authors classify existing knowledge. This grouped knowledge functions as a filter or advanced search.
1) For Infrastructure Management and Information Technology Subdivision

Table 4:

Knowledge Mapping for Infrastructure Management and Information Technology Subdivision

\begin{tabular}{|l|l|}
\hline Topic & Subtopic \\
\hline Backup & Cold Backup \\
\hline & Hot Backup \\
\hline Cloud Storage & Warm Backup \\
\hline & Cloud Document \\
\hline & Network Area Storage \\
\hline Colocation & Upgrade Storage \\
\hline Hosting & IP request \\
\hline & Database access \\
\hline & Backup database \\
\hline & Operation system downgrade \\
\hline & Web Framework Installation \\
\hline & Web Service Installation \\
\hline & Operation System Configuration \\
\hline & Server Migration \\
\hline & Server Request \\
\hline & Remote Access \\
\hline & Service Upgrade \\
\hline & Information System Upgrade \\
\hline Internal & IP Usage \\
\hline & IP switch \\
\hline Network & Dialup Tunnel Client \\
\hline & IPSec Dialup Tunnel \\
\hline & IPSec Site to Site unnel \\
\hline & Load Balancing \\
\hline & Cable Network Installation \\
\hline Security & SSID Addition \\
\hline & Web Application Firewall \\
& Activation \\
\hline & Antivirus \\
\hline & Create User Access \\
\hline & Open Service (Port) \\
\hline & SSL request \\
\hline & Security Test \\
\hline & Other \\
\hline & \\
\hline & \\
\hline &
\end{tabular}

2) For Information System Development Division

Table 5:

Knowledge Mapping for Information System Development

\begin{tabular}{|l|l|}
\hline Topic & Sub-Topic \\
\hline Technical knowledge & Programming \\
\hline & Query \\
\hline Tools Usage & Tools A Usage \\
\hline & Tools B Usage \\
\hline Information System Project & Project Case \\
\hline & Document for Project \\
\hline & Project Method \\
\hline
\end{tabular}




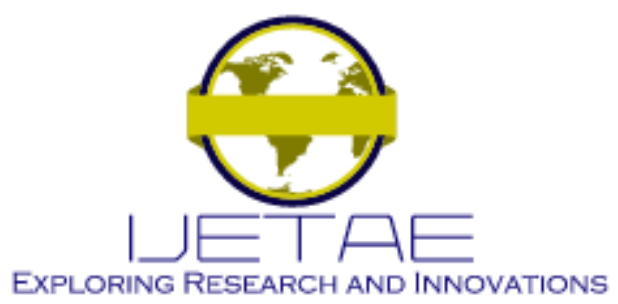

International Journal of Emerging Technology and Advanced Engineering

Website: www.ijetae.com (E-ISSN 2250-2459, Scopus Indexed, ISO 9001:2008 Certified Journal, Volume 11, Issue 11, November 2021)

\section{Profile and Policies}

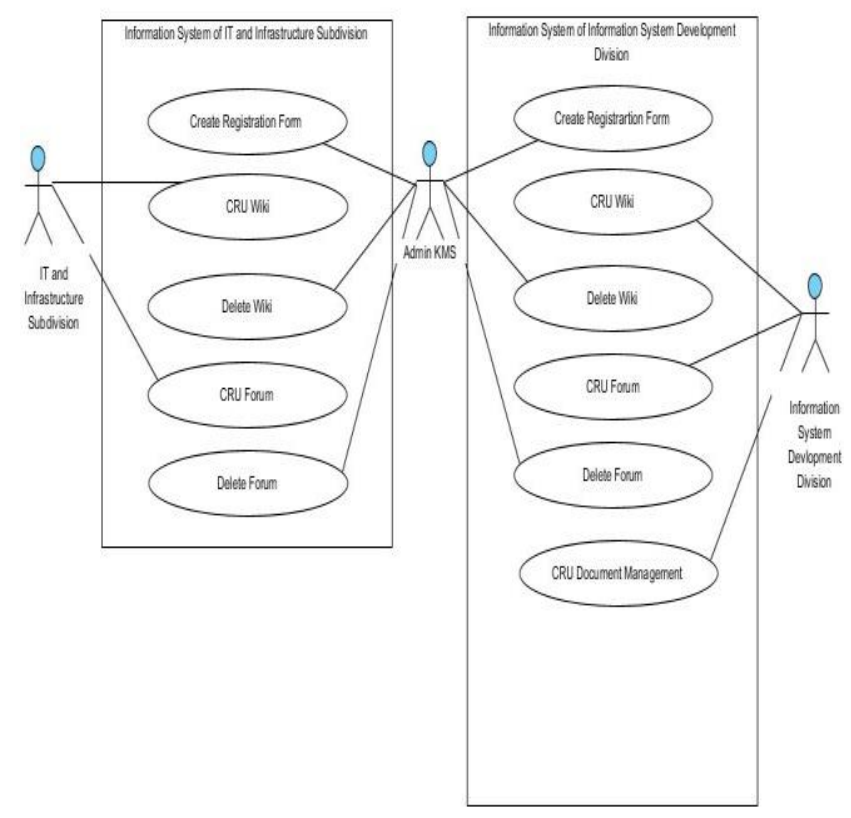

Figure 6 : Use Case Diagram

\section{Design and Integrating Big Data}

In the design and integerating big data phase, the author designs a framework for big data itself and maps big data to a knowledge management system. The big data framework designed here focuses on extract, transform, load (ETL).

\section{1) Big Data Framework}

Knowledge Database is data that comes from wiki and forum that have been created in KMS. Website, Office 365, File Sharing, Knowledge database included in ETL. The data sources transform to XML. Social Media and Youtube transferred via Apache Floop to Data Warehouse. Then after the ETL enters the data warehouse to be stored and later used as recommendations and queries. These recommendations can be wikis or frequently searched forums. This query is used to search on search engines.

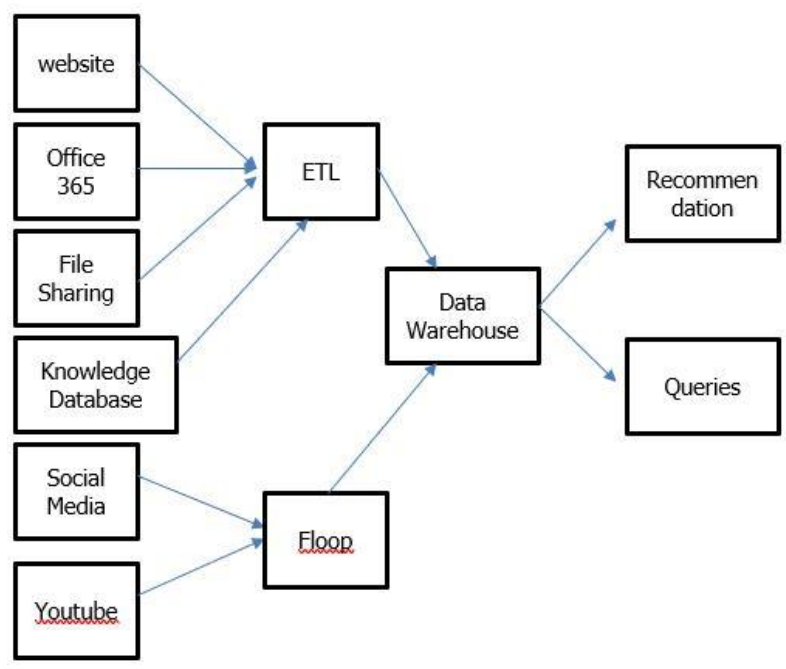

Figure 7 : Big Data Framework

\section{2) Mapping Big Data to KMS}

Mapping big data is how to integrate the knowledge management system with big data so that it can be useful for sharing knowledge in the Information Technology and Infrastructure Management Subdivision and Information System Development Division. Big Data here is a file search engine in various forms and is built on Apache Hadoop. The search results are in the form of SQL queries that generate meta data and files contained in the Data and Information Center. Search results are collective, so there must be references to the results provided by search engines, be it wikis, forums or document management.

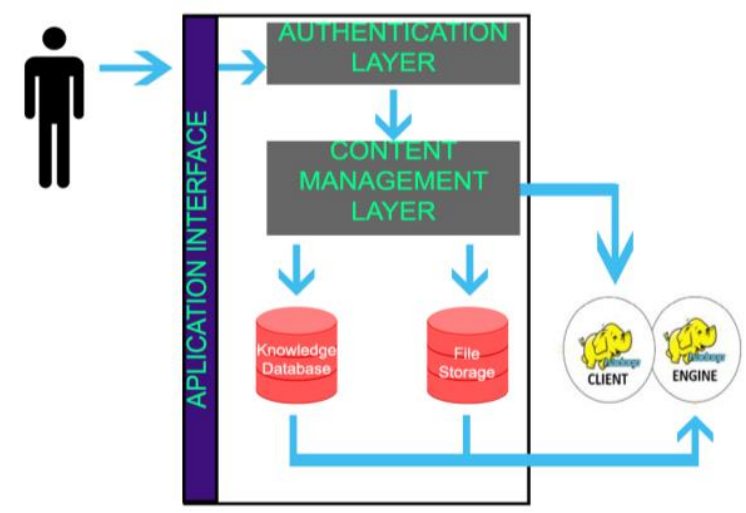

Figure 8 : Mapping Big Data to KMS 


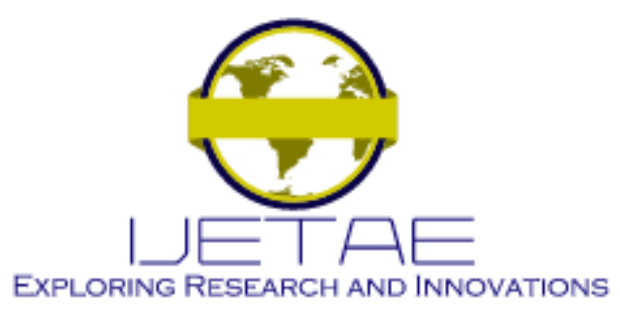

International Journal of Emerging Technology and Advanced Engineering

Website: www.ijetae.com (E-ISSN 2250-2459, Scopus Indexed, ISO 9001:2008 Certified Journal, Volume 11, Issue 11, November 2021)

\section{E. Design Knowledge Management System User Interface}

\section{1) Login Page}

On login page, the user must enter a username and password.

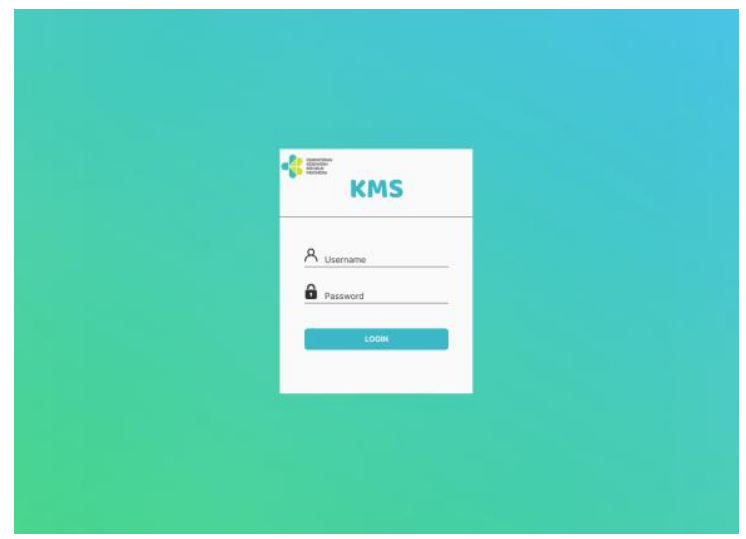

Figure 9 : UI Login Page

2) Main Page

On front page there are menus, KMS search engine features, new wikis, popular wikis, forums and activity.

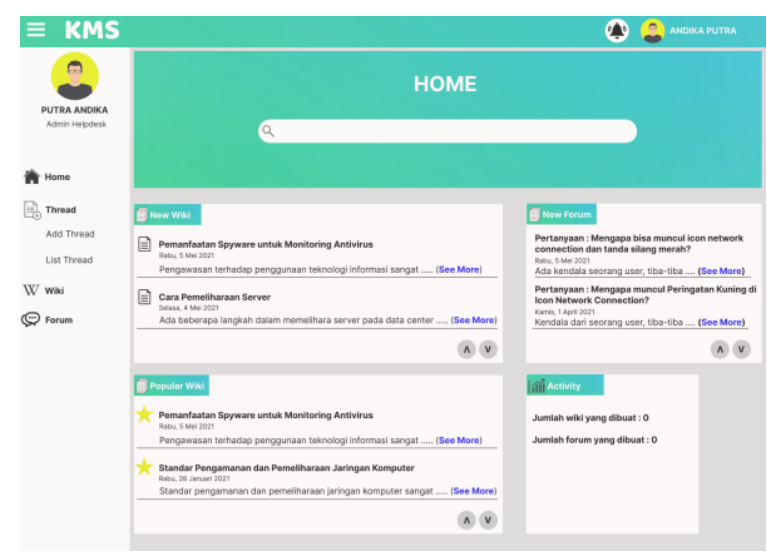

Figure 10 : UI Main Page

3) Search Engine Page

This search engine page appears after the user searches for a keyword in the KMS search engine feature on the front page.
On this search engine page there are advanced search, date modified, and an area to display what you are looking for.

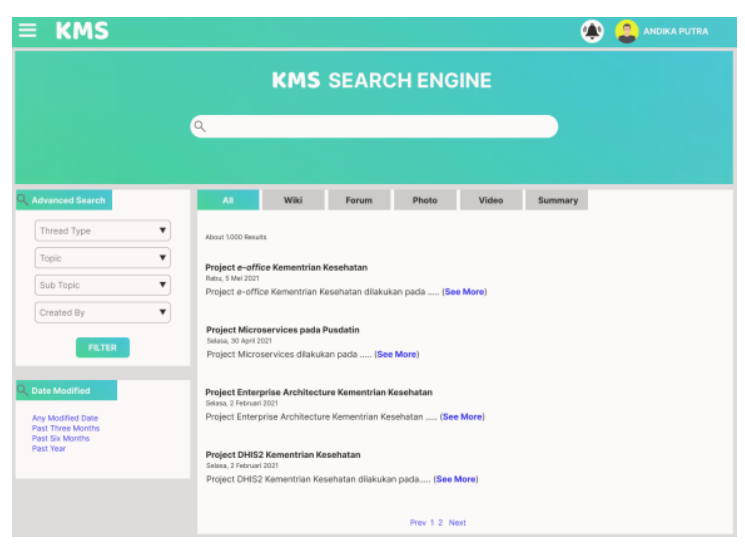

Figure 11 : UI Search Engine Page

4) Wiki Page

Wiki page is similar to wikipedia in that it is a one-way article. On this wiki page there are advanced search, date modified, saved wiki, wiki area.

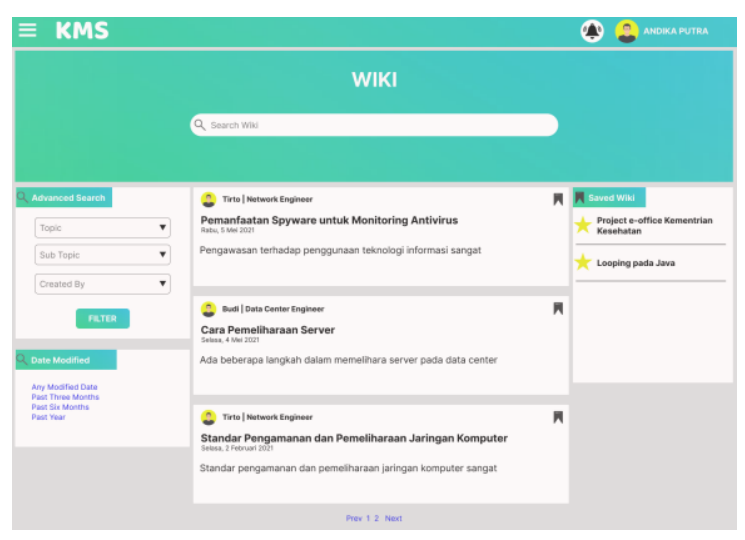

Figure 12 : UI Search Engine Page

5) View Wiki

This page shows more if we have clicked on one of the existing wiki articles. 


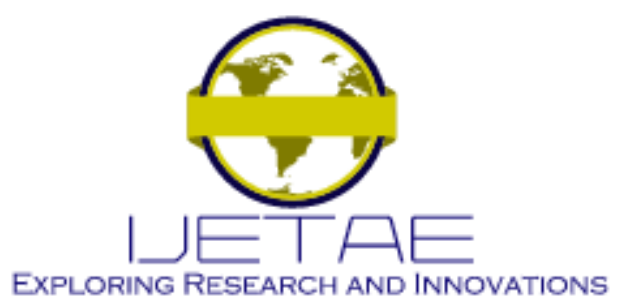

International Journal of Emerging Technology and Advanced Engineering Website: www.ijetae.com (E-ISSN 2250-2459, Scopus Indexed, ISO 9001:2008 Certified Journal, Volume 11, Issue 11, November 2021)

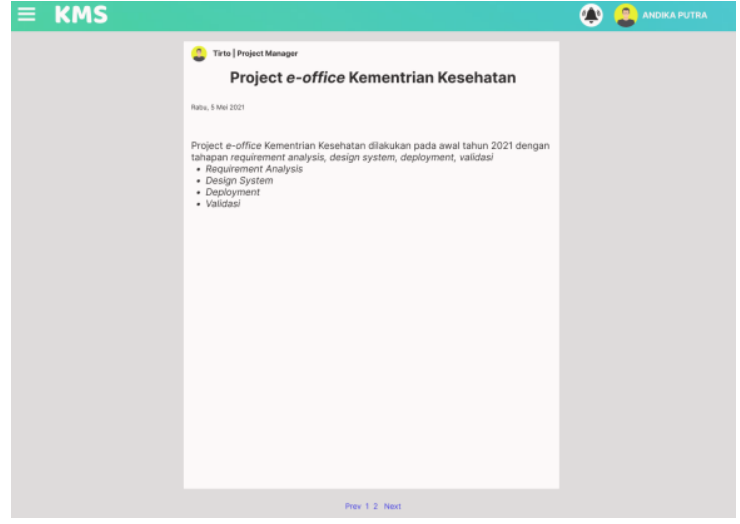

Figure 13 : UI View Wiki

6) Forum Page

On forum page there are advanced search, date modified, forum area, saved wiki.

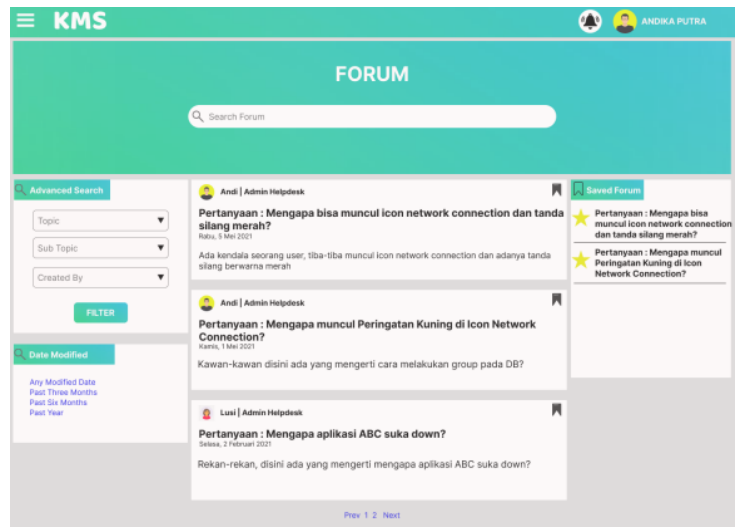

Figure 14 : UI Forum Page

\section{7) View Forum}

On this page more shows if we have clicked on one of the existing forums.

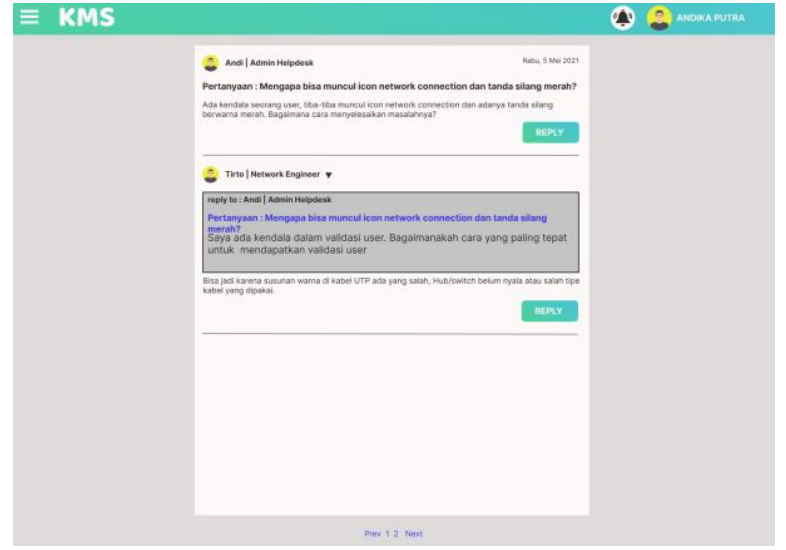

Figure 15 : View Forum

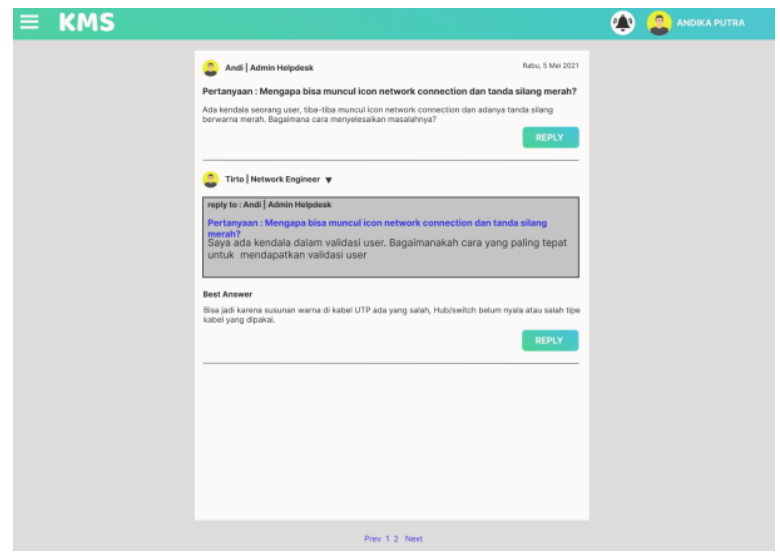

Figure 16 : UI Forum Page

The display of the forum view in the subdivision of infrastructure management and information technology because it only wants interaction between 1 staff and 1 other staff, then 1 staff who asks at the forum can choose which is the best answer from the staff who answers the question and then the best answer will be displayed. 


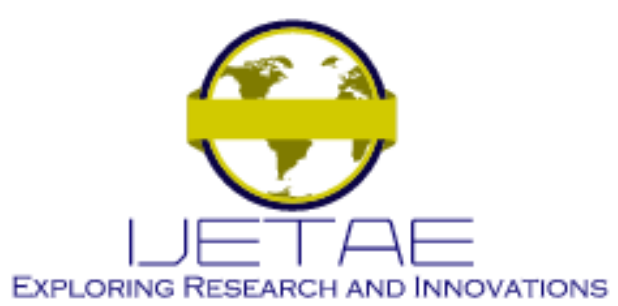

International Journal of Emerging Technology and Advanced Engineering

Website: www.ijetae.com (E-ISSN 2250-2459, Scopus Indexed, ISO 9001:2008 Certified Journal, Volume 11, Issue 11, November 2021)

8) Add Wiki

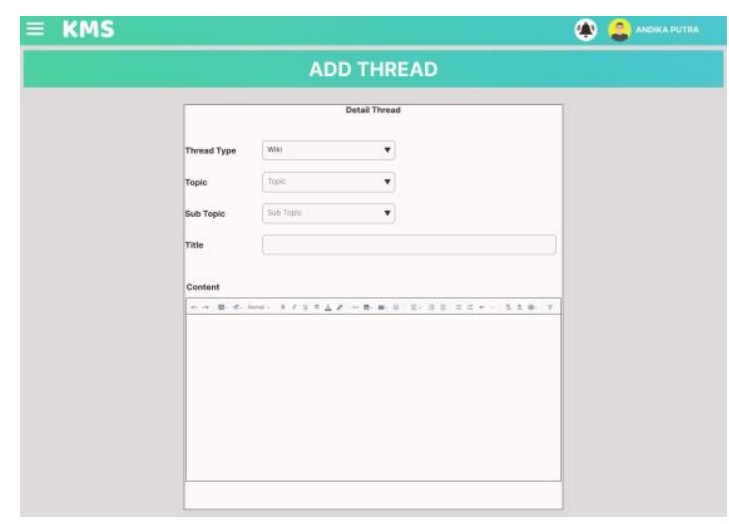

Figure 17 : UI Add Wiki and Fill Content

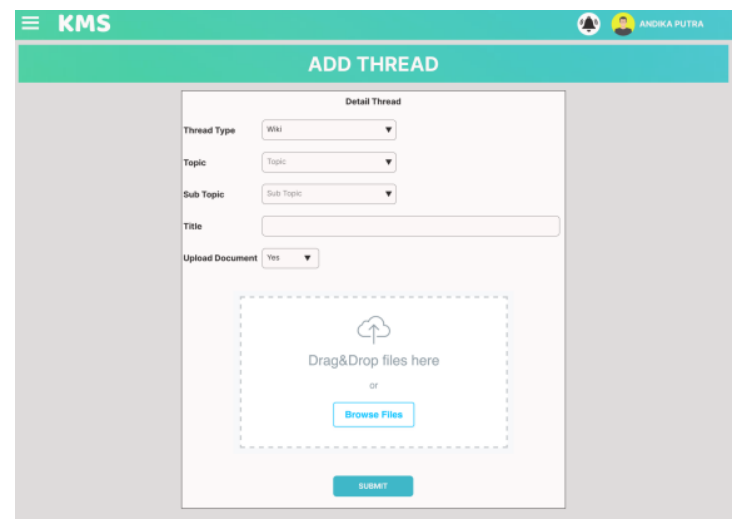

Figure 18 : UI Add Wiki and Upload Document

\section{9) Add Forum}

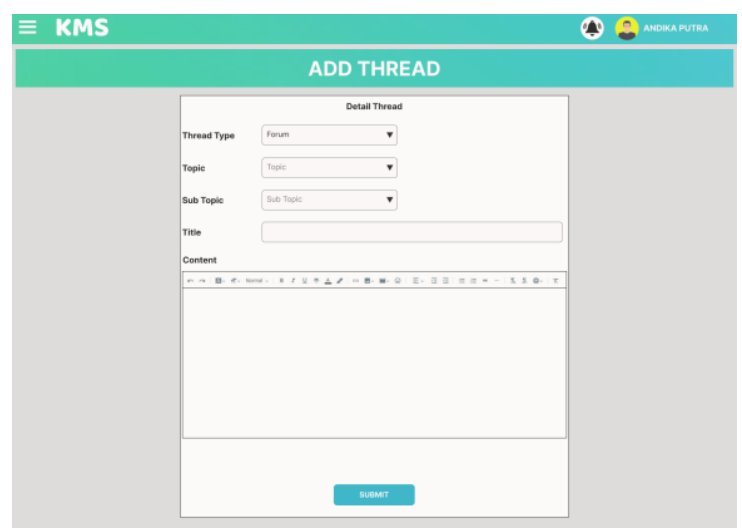

Figure 19 : UI Add Forum
10) Document Management

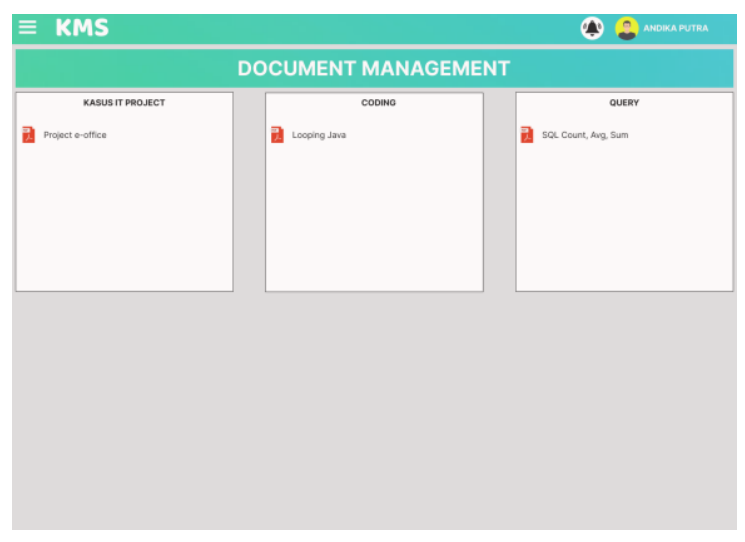

Figure 20 : UI Document Management

\section{1) Add Document Management}

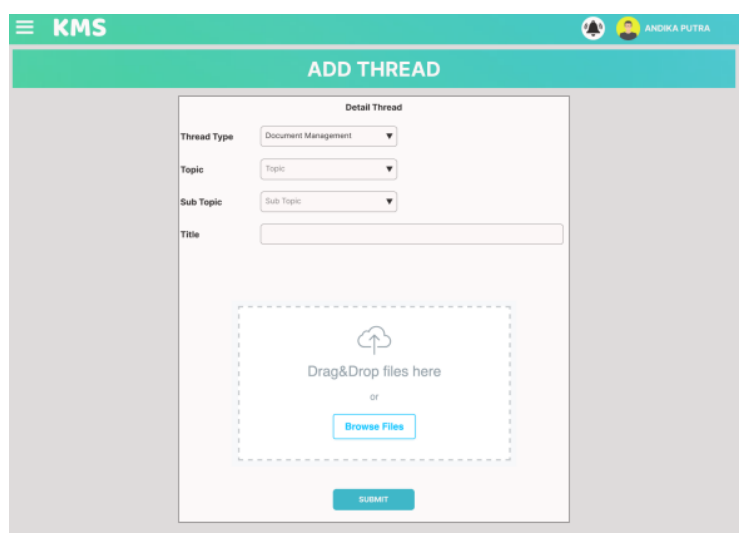

Figure 21 : UI Add Document Management

\section{CONCLUSION}

The conclusions that can be drawn from the design of the knowledge management system at the Data and Information Center of the Ministry of Health are that the application of a good knowledge management system will help the Data and Information Center of the Ministry of Health to manage existing knowledge, increase knowledge sharing among employees and the creation of new knowledge by employees of the Data and Information Center of the Ministry of Health. The existence of a forum to accommodate and share existing knowledge at the Data and Information Center of the Ministry of Health creates productivity for the staff of the Data and Information Center of the Ministry of Health. 


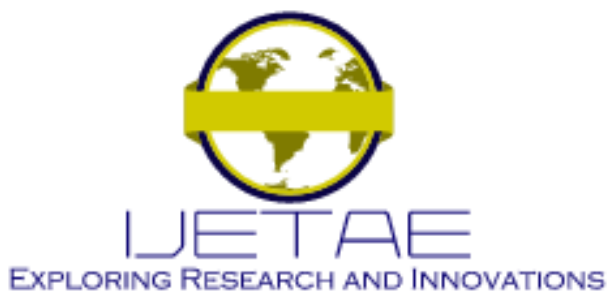

International Journal of Emerging Technology and Advanced Engineering Website: www.ijetae.com (E-ISSN 2250-2459, Scopus Indexed, ISO 9001:2008 Certified Journal, Volume 11, Issue 11, November 2021)

The application of a big data-based knowledge management system will assist the Ministry of Health's Center for Data and Information in integrating data from data sources and entering it into the data warehouse.

\section{REFERENCES}

[1] M. Laal, "Knowledge management in higher education," in Procedia Computer Science, 2011, vol. 3, doi: 10.1016/j.procs.2010.12.090.

[2] E. Turban, J. Whiteside, D. King, and J. Outland, "Innovative EC Systems: From E-Government to E-Learning, Knowledge Management, E-Health, and C2C Commerce," 2017.

[3] Y. Merali, "The Organic Metaphor in Knowledge Management," Emergence, vol. 2, no. 4, 2000, doi: 10.1207/s15327000em0204_04.

[4] E. O. Makori, "Contemporary issues in information management: A fresh look for information professionals," Int. J. Libr. Inf. Sci., vol. 1, no. 6, 2009 .

[5] K. M. Wiig, "1999 Introducing KM into the Enterprise," no. January 1999, 2016.

[6] I. Nonaka and H. Takeuchi, "The knowledge-creating company: How Japanese companies create the dynamics of innovation," Long Range Plann., vol. 29, no. 4, 1996, doi: 10.1016/00246301(96)81509-3.

[7] P. Carrillo, H. Robinson, A. Al-Ghassani, and C. Anumba, "Knowledge Management in UK Construction: Strategies, Resources and Barriers," Proj. Manag. J., vol. 35, no. 1, 2004, doi: $10.1177 / 875697280403500105$.
[8] C. T. Townley, "Knowledge management and academic libraries," Coll. Res. Libr., vol. 62, no. 1, 2001, doi: 10.5860/crl.62.1.44.

[9] K. Dalkir, "Introduction to Knowledge Management in Theory and Practice," in Knowledge Management in Theory and Practice, 2020.

[10] D. Nevo, "Developing Effective Knowledge Management Systems," Univ. Br. Columbia, 2003.

[11] Y. M. Wang and Y. C. Wang, "Determinants of firms' knowledge management system implementation: An empirical study," Comput. Human Behav., vol. 64, 2016, doi: 10.1016/j.chb.2016.07.055.

[12] J. O'Brien, "The Construction of an Operational-Level Knowledge Management Framework.," Proc. Int. Conf. Intellect. Capital, Knowl. Manag. Organ. Learn., 2013.

[13] A. Tiwana, Knowledge Management Toolkit , The Amrit Tiwana Knowledge Management Toolkit, The. 1999.

[14] M. A. Mostefai, A. Annane, L. Kissoum, and M. Ahmed-Nacer, "Implementing knowledge management systems in cloud-based environments: A case study in a computer science high school," 2015, doi: 10.1109/CloudTech.2015.7337008.

[15] F. Amalina et al., "Blending Big Data Analytics: Review on Challenges and a Recent Study," IEEE Access, vol. 8. 2020, doi: 10.1109/ACCESS.2019.2923270.

[16] T. R. Perdana, S. Mujiatun, S. Sfenrianto, and E. R. Kaburuan, "Designing knowledge management system with big data for hospital inpatient services: (case study at Islamic Hospital XYZ Pekanbaru)," 2019, doi: 10.1109/ICOIACT46704.2019.8938469.

[17] R. Wijaya and B. Pudjoatmodjo, "Penerapan ExtractionTransformation-Loading (ETL) Dalam Data Warehouse (Studi Kasus : Departemen Pertanian),” J. Nas. Pendidik. Tek. Inform., vol. 5, no. 2, 2016, doi: 10.23887/janapati.v5i2.9855. 